\title{
PENERAPAN MODEL PROBLEM BASED LEARNING UNTUK MENINGKATKAN HASIL BELAJAR PESERTA DIDIK PADA MATA PELAJARAN SIMULASI DIGITAL
}

\author{
Ninu Marlina ${ }^{1)}$, Alfadl Habibie ${ }^{2)}$, Sulidar Fitri ${ }^{3)}$ \\ 1) Pendidikan Teknologi Informasi FKIP Universitas Muhammadiyah Tasikmalaya \\ Email:ninumarlina3@gmail.com ${ }^{l)}, \underline{\text { Alfadl @umtas.ac.id }{ }^{2} \text {, sfitri@umtas.ac.id }{ }^{3)}}$
}

\begin{abstract}
Abstraksi
Model pembelajaran Problem Based Learning adalah model pembelajaran yang menuntut peserta didik untuk belajar mandiri secara individu maupun kelompok dalam memecahkan masalah yang disajikan oleh guru. Pada penelitian ini bertujuan untuk mengetahui ada atau tidaknya peningkatan hasil belajar peserta didik bila diterapkan model pembelajaran Problem Based Learning pada mata pelajaran simulasi digital kelas X SMK Angkasa Tasikmalaya. Jenis penelitian yang digunakan adalah kuantitatif, sedangkan metodenya adalah preexperimental desain one grup pretes-posttes design. Subjek penelitian adalah seluruh peserta didik kelas X SMK Angkasa Tasikmalaya dengan jumlah 32 orang. Teknik pengumpulan data berupa observasi dan wawancara kepada guru mata pelajaran. Hasil penelitian menunjukan bahwa model Problem Based Learning berpengaruh terhadap hasil belajar peserta didik. Hal tersebut dapat dilihat dari adanya peningkatan nilai hasil pre test dan post test peserta didik. Rata-rata skor pre test yaitu sebesar 55.09 mengalami peningkatan pada nilai rata-rata post test menjadi 75.87. Berdasarkan hasil uji paired t-test, menunjukkan bahwa nilai thitung sebesar $6,713 \geq t_{\text {tabel }}$ yaitu $0.68(6,713>0.68)$ dan nilai signifikansi 0,000 < 0.05. Artinya bahwa model Problem Based Learning berpengaruh signifikan terhadap hasil belajar peserta didik.
\end{abstract}

Kata Kunci : Penerapan, Problem Based Learning, Hasil Belajar

\begin{abstract}
Problem Based Learning learning model is a learning model that requires students to learn independently individually or in groups in solving problems presented by the teacher. This study aims to determine whether or not there is an increase in student learning outcomes when the Problem Based Learning learning model is applied to digital simulation subjects in class X SMK Angkasa Tasikmalaya. This type of research is quantitative, while the method is pre-experimental design one group pretest-posttest design. The subjects were all students of class $X$ SMK Angkasa Tasikmalaya with the number 32. Data collection techniques in the form of observation and interviews with subject teachers. The results showed that the Problem Based Learning model had an effect on the learning outcomes of students. It can be seen from the increase in the value of the pre-test and post-test learners. The average pre-test score was 55.09, an increase in the average post-test score to 75.87. Based on the results of the paired $t$-test, it shows that the $t$-count value is $6,713 \geq t$-table, namely $0.68(6,713>0.68)$ and a significance value of 0,000<0.05. This means that the Problem Based Learning model has a significant effect on student learning outcomes.
\end{abstract}

Keywords : Application, Problem Based Learning, Learning Outcomes.

\section{PENDAHULUAN}

Seseorang yang telah lulus dari suatu tingkat pendidikan akan berhadapan dengan dunia kerja. Dimana kemampuan berpikir tinggi, pemecahan masalah dan mampu bekerja sendiri maupun bekerjasama sangat dibutuhkan oleh suatu perusahaan atau instansi, maka pendidikan harus menyiapkan lulusan yang berkualitas sehingga bisa bersaing didunia kerja. Pendidikan merupakan sebuah proses yang membantu menumbuhkan, mengembangkan, mendewasakan, membuat yang tidak tertata menjadi tertata, semacam proses penciptaan sebuah qultur dan tata keteraturan dalam diri maupun dalam diri orang lain [1]. 
Dari hasil wawancara dengan guru mata pelajaran, menghasilkan beberapa data dimana rata-rata hasil belajar peserta didik pada mata pelajaran simulasi digital sebesar 70.8 menandakan masih berada di bawah KKM yaitu 75. Dari jumlah peserta didik 54 orang, ada 18 orang yang memiliki nilai lebih dari 75 . Hal ini bisa terjadi karena penerapan model pembelajaran yang kurang tepat, maka dari itu peneliti ingin menerapkan model Problem Based Learning, karena pada model ini peserta didik harus mampu menyelesaikan suatu permasalahan dari kehidupan nyata, sehingga peserta didik dituntut untuk berpikir kritis. Dengan berpikir kritis akan mendorong peserta didik rajin membaca untuk menemukan solusi dari setiap permasalahan yang diberikan. Apalagi pada mata pelajaran simulasi digital yang merupakan salah satu mata pelajaran baru disemua kompetensi keahlian pada kurikulum 2013 dan masuk kedalam mata pelajaran kompetensi sebagai suatu keahlian dalam Teknik Jaringan Komputer atau TKJ, mengharuskan peserta didik menguasainya, karena sesuai dengan revolusi 4.0 dimana perkembangan teknologi sangat pesat.

Maka tujuan dari penelitian ini adalah untuk mengetahui penerapan model pembelajaran Problem Based Learning pada mata pelajaran simulasi digital di kelas X SMK Angkasa Tasikmalaya, untuk mengetahui peningkatan terhadap hasil belajar peserta didik setelah diterapkan model pembelajaran Problem Based Learning pada mata pelajaran simulasi digital dan untuk mengetahui pengaruh model problem peningkatan hasil belajar peserta didik setelah diterapkan model Problem Based learning. Agar penelitian tidak melebar kemana- mana maka peneliti membatasi hanya pada: penelitian ini dilakukan di kelas X SMK Angkasa Tasikmalaya Semester ganjil 2020/2021, penelitian ini dilakukan secara daring melalui aplikasi whatssapp, model pembelajaran yang digunakan adalah model Problem Based Learning, penerapan model Problem Based Learning ini dikhususkan untuk materi Menerapkan logika dan algoritma komputer dalam Kompetensi Dasar 3.1 dan Kompetensi Dasar 4.1 yaitu Menggunakan fungsi-fungsi perintah (Command) pada mata pelajaran simulasi digital dan hasil belajar dicapai melalui proses belajar mengajar pada materi Menerapkan logika dan algoritma komputer dalam Kompetensi Dasar 3.1 dan Kompetensi Dasar 4.1 yaitu Menggunakan fungsi-fungsi perintah (Command).

Penelitian ini dapat memberikan pengetahuan untuk guru dalam menerapkan model pembelajaran yang berpusat pada peserta didik yaitu model Problem Based Learning khususnya pada mata pelajaran simulasi digital dan membantu peserta didik dalam mengembangkan kemampuan berpikir.

\section{a. Hakikat Pembelajaran}

Pembelajaran berasal dari kata belajar lalu diberi imbuhan pem- an. Belajar adalah suatu proses perubahan baik itu perubahan pengetahuan, keterampilan dan tingkah laku pada seseorang yang didapat dari mana saja dan berlangsung seumur hidup. Jadi pembelajaran adalah suatu proses pemberian ilmu dari pendidik ke peserta didik yang terencana dalam lingkungan yang sengaja dikelola untuk membuat peserta didik belajar aktif.

\section{b. Model Pembelajaran}

Menurut Ruseffendi (dalam buku Hamdayama 2016:127-128), istilah strategi, metode dan pendekatan telah didefinisikan sebagai berikut: Strategi pembelajaran adalah seperangkat kebijaksanaan yang terpilih, yang telah dikaitkan dengan faktor yang menentukan warna atau strategi tersebut [2]. Pendekatan pembelajaran adalah jalan atau arah yang ditempuh oleh guru atau peserta didik dalam mencapai tujuan pembelajaran dilihat bagaimana materi itu disajikan. Metode pembelajaran adalah cara mengajar secara umum yang dapat diterapkan pada semua mata pelajaran. Teknik mengajar adalah penerapan secara khusus suatu metode pembelajaran yang telah disesuaikan dengan kemampuan dan kebiasaan guru, ketersediaan media pembelajaran serta kesiapan peserta didik.

\section{c. Model Problem Based Learning}

Menurut Nurhadi (2004: 109), PBL adalah suatu model pembelajaran yang menggunakan masalah dunia nyata sebagai suatu konteks bagi peserta didik untuk belajar tentang cara berpikir kritis dan keterampilan pemecahan masalah serta untuk memperoleh pengetahuan dan konsep yang esensial dari materi pelajaran [4].

\section{d. Kelebihan dan Kekurangan PBL}

Kelebihan model PBL adalah pemecahan masalah merupakan teknik yang baik untuk lebih memahami isi pelajaran, pemecahan masalah dapat menantang kemampuan peserta didik serta memberi kepuasan untuk menemukan pengetahuan baru, pemecahan masalah dapat meningkatkan aktivitas peserta didik, pemecahan masalah membantu bagaimana mentransfer pengetahuan mereka untuk memahami masalah dalam kehidupan nyata, pemecahan masalah dapat membantu peserta didik untuk mengembangkan pengetahuan barunya dan bertanggungjawab terhadap pembelajaran yang mereka lakukan[5].

Kekurangan model PBL adalah jika minat peserta didik kurang atau masalah kurang menarik peserta didik, maka peserta didik akan merasa enggan untuk mencoba, keberhasilan strategi pembelajaran berbasis masalah 
membutuhkan cukup waktu untuk persiapan dan tanpa pemahaman mengapa mereka berusaha memecahkan masalah yang sedang dipelajari, maka mereka tidak akan belajar apa yang ingin mereka pelajari [8].

\section{e. Hasil Belajar}

Rusmono (2012: 10) mengemukanan bahwa hasil belajar merupakan perubahan perilaku individu yang meliputi ranah kognitif, afektif, dan psikomotor. Maka dapat disumpulkan bahwa hasil belajar adalah perubahan perilaku individu yang meliputi ranah kognitif, afektif, dan psikomotor setelah menerima pengalaman belajarnya [5]. Namun pada penelitian ini, aspek hasil belajar yang diteliti adalah hanya pada ranah kognitif atau pengetahuan, hal ini dikarenakan sulit untuk meneliti ranah afektif atau sikap dan psikomotor atau keterampilan pada saat pembelajaran via aplikasi grup whatsapp.

\section{f. Mata Pelajaran Simulasi Digital}

Menurut kamus besar Bahasa Indonesia mata pelajaran adalah pelajaran yang harus di ajarkan sekolah dasar sampai sekolah lanjutan. Simulasi digital adalah salah satu mata pelajaran baru disemua kompetensi keahlian pada kurikulum 2013 dan merupakan kompetensi sebagai suatu keahlian dalam Teknik Jaringan Komputer atau TKJ. Mata pelajaran simulasi digital dipelajari oleh peserta didik kelas X semua sekolah kejuruan. Mata pelajaran simulasi digital adalah mata pelajaran yang akan membekali para peserta didik agar dapat mengomunikasikan gagasan atau ide pemikiran atau konsep melalui media digital.

\section{METODE PENELITIAN}

Metode yang digunakan adalah metode eksperimen karena dapat mencari pengaruh perlakuan terhadap yang lain dalam kondisi yang terkendalikan [6]. Sedangkan desain pada penelitian ini adalah pre-experimental design. Dalam penelitian pre-eksperimental design ini tidak menggunakan kelas kontrol sehingga variabel luar masih bisa berpengaruh terhadap terbentuknya variabel dependen. Dalam penelitian ini desain yang digunakan adalah One Grup Pretes-Posttes design. Digunakannya desain pre-ekperimental dengan bentuk one grup pretes posttes ini karena kebijakan dari pihak sekolah yang tidak mengizinkan hanya menggunakan 2 kelas, jadi semua kelas $\mathrm{X}$ harus diajarkan secara bersama-sama dalam satu grup whatsapp. Desain ini dapat digambarkan sebagai berikut [7]

Tabel.1

\begin{tabular}{|c|c|c|}
\hline \multicolumn{3}{|c|}{ One Grup Pretes Posttes Design } \\
\hline Pretest & Variabel Terikat & Posttest \\
\hline $\mathrm{O} 1$ & $\mathrm{X}$ & $\mathrm{O} 2$ \\
\hline
\end{tabular}

Keterangan:

$\begin{array}{ll}\mathrm{O} 1 & : \text { pretest } \\ \mathrm{O} 2 & \text { : posttest } \\ \mathrm{X} & \text { : treatment / perlakuan pada penelitian ini adalah penggunaan model Problem Based Learning. }\end{array}$

Populasi pada penelitian adalah peserta didik kelas X SMK Angkasa Tasikmalaya sebanyak 47 orang peserta didik. Teknik pengambilan sampel yaitu total sampling dimana anggota populasi digunakan sebagai sampel. Sehingga sampel yang digunakan yaitu peserta didik kelas X TKR sebanyak 17 orang dan peserta didik kelas X RPL sebanyak 10 orang, peserta didik kelas TBSM sebanyak 17 orang dan peserta didik kelas X TAV sebanyak 3 orang SMK Angkasa Tasikmalaya sehingga jumlah sampel sebanyak 47 orang. Dikarenakan proses pembelajaran dilakukan menggunakan aplikasi whatsapp maka sampel yang digunakan hanya peserta didik yang bisa mengakses aplikasi whatsapp saja, yaitu sebanyak 32 peserta didik.

Variabel dalam penelitian ini terdiri dari 2 jenis, yaitu variabel terikat dan variabel bebas. Variabel bebas adalah variabel yang mempengaruhi atau yang menjadi sebab yaitu model pembelajaran Problem Based Learning (PBL), sedangkan variabel terikat adalah variabel yang dipengaruhi oleh variabel bebas yaitu hasil belajar peserta didik kelas X SMK Angkasa Tasikmalaya.

Teknik pengumpulan data yang dilakukan pada penelitian ini adalah wawancara dan tes. Wawancara digunakan untuk mengetahui data awal tentang sekolah, peserta didik dan lainnya. Sedangkan tes dilakukan sebanyak dua kali yaitu pretes yang dilakukan sebelum pemberian perlakuan dan posttes yang dilakukan sesudah perlakuan, hal ini dilakukan untuk mencari nilai hasil belajar peserta didik. Instrumen yang digunakan yaitu 
lembar tes. Sebelum diberikan kepada peserta didik, lembar tes ini diuji validitas dan reliabilitasnya. Jika lembar tes sudah valid dan dapat dipercaya atau reliabel maka lembar tes dapat digunakan untuk penelitian. Tahap terakhir adalah analisis data yang dilakukan pada beberapa tahap yaitu Statistik deskriptif, uji normalitas, uji homogenitas dan uji hipotesis.

\section{HASIL DAN PEMBAHASAN}

\section{A. Hasil Penelitian}

1. Deskripsi Penerapan PBL

Proses pembelajaran simulasi digital ini dilakukan sebanyak 3 kali pertemuan, yaitu pada tanggal 7, 8 dan 14 Agustus 2020. Pada pertemuan pertama pembelajaran mengenai konsep logika, pertemuan kedua membahas tentang menyusun flowchart contoh algoritma sederhana dalam kehidupan sehari-hari dan pertemuan ke tiga mengenai fungsi dari tiap simbol flowchart dan perintah dalam CMD.

Adapun teknis dari penerapan model Problem Based Learning melalui aplikasi whatsapp ialah sebagai berikut: guru memasukan peserta didik kelas X SMK Angkasa Tasikmalaya kedalam grup whatsapp yang sudah dibuat. Setelah itu guru menjelaskan bahwa pada pembelajaran ini dilakukan melalui aplikasi whatsapp, absensi dilihat dari peserta didik yang mengisi absensi dengan menuliskan Nama dan kelas. Implementasi model Problem Based Learning ini dilakukan melalui beberapa tahap, yaitu:

a. Tahap orientasi peserta didik pada masalah. Pada tahap ini guru menjelaskan tahapan dalam Problem Based Learning. Guru memberikan permasalahan dunia nyata terkait logika dan algoritma, permasalahan diberikan ke peserta didik berupa cerita yaitu pertemuan pertama cerita tentang seorang anak yang terjebak disuatu lubang besar, bagaimana cara peserta didik mencari cara agar bisa keluar dari lubang tersebut jika ada beberapa barang yang bisa dia gunakan, pertemuan kedua mengenai penyusunan flowchart contoh algoritma sederhana dalam kehidupan sehari-hari, yaitu permasalahan dalam membuat flowchart untuk menghitung luas segitiga dan pertemuan ketiga mengenai pembuatan alur cerita pembuatan animasi produk penjualan. Permasalahan diberikan dalam bentuk word yang dikirim melalui aplikasi whatsapp. Lalu peserta didik memahami masalah yang diberikan dan dipersilahkan bertanya apabila ada yang mau ditanyakan melalui voice note atau komentar biasa.

b. Tahap organisasi peserta didik untuk belajar. Pada tahap ini guru membagi peserta didik kedalam 6 kelompok yang terdiri dari 4-5 orang dalam satu kelompok, lalu guru memberikan lembar kerja kepada tiap kelompok dalam bentuk word melalui grup whatsapp yang sudah dibuat. Lembar kerja siswa ini berisi permasalahan pada tahap orientasi untuk didiskusikan bersama teman kelompoknya melalui grup whatsap yang mereka buat khusus untuk anggota kelompoknya. Lalu guru mempersilahkan tiap-tiap kelompok untuk mencari informasi.

c. Tahap membimbing penyelidikan individu maupun kelompok. Pada tahap ini guru membimbing penyelidikan peserta didik untuk solusi dari permasalahan. Penyelidikan ini berupa penginstruksian pembagian tugas kerja, penginstruksian ini diberikan kepada peserta didik agar semua anggota kelompok bekerjasama dalam pemecahan masalah yang diberikan.

d. Tahap menyajikan hasil kerja kelompok yaitu guru memotivasi peserta didik untuk berani melaporkan atau mempresentasikan hasil kerja kelompoknya melalui voice note dan mengirimkan hasil kerja kelompok di grup whatsapp didepan teman yang lainnya.

e. Tahap terakhir adalah mengevaluasi proses pemecahan masalah yaitu guru membantu peserta didik untuk melakukan evaluasi terhadap proses yang digunakan. Evaluasi ini berupa kesimpulan dari solusi yang tepat terhadap permasalahan yang diberikan melalui aplikasi whatsapp berupa voive note atau komentar.

\section{Hasil Pretes dan Posttes}

Berikut disajikan ringkasan hasil dari pretes dan posttes dengan menggunakan model Problem Based Learning dalam bentuk tabel.

Tabel.1.

Rekapitulasi Pretes dan Posttes

\begin{tabular}{|l|l|l|l|l|l|l|l|l|}
\hline Kelompok & N & Max & Min & Sd & $\begin{array}{l}\text { Rata- } \\
\text { Rata }\end{array}$ & selisih & Persen & Kategori \\
\hline Pretes & 32 & 88 & 23 & 17,41 & 54,90 & \multirow{2}{*}{20,96} & \multirow{2}{*}{$50,19 \%$} & $\begin{array}{l}\text { Sangat } \\
\text { baik }\end{array}$ \\
\hline posttes & 32 & 94 & 29 & 16,64 & 75,87 & & \\
\hline
\end{tabular}


Dilihat dari tabel rekap pretes dan posttes di atas, nilai max dari pretes adalah 88 sedangkan pada posttes adalah 94, nilai minimal pretes adalah 23, sedangkan nilai minimal posttes adalah 29. Standar deviasi atau ukuran variasi data pada pretes adalah 17.41 sedangkan posttes 16.64. Rata-rata pada pretes adalah 54.90 dan posttes 75.87 dengan selisih sebanyak 20.96 jika dipersenkan menjadi 50.19\% kenaikan dari nilai pretes ke posttes.

3. Uji statistik hasil belajar peserta didik

a. Uji Normalitas

Uji normalitas pada penelitian ini menggunakan uji Shapiro Wilk dikarenakan sampel yang kurang dari 100 yaitu berjumlah 32 orang dan taraf signifikan 5\%, Berikut hasil uji normalitas dengan menggunakan aplikasi SPSS versi 25:

Tabel.2.

\begin{tabular}{|l|c|r|}
\multicolumn{3}{c}{ Hasil Uji Normalitas } \\
\hline Kelompok & $\mathrm{N}$ & signifikansi \\
\hline Pretes & 32 & .105 \\
\hline Posttes & 32 & .088 \\
\hline
\end{tabular}

Berdasarkan tabel di atas diperoleh nilai signifikansi pretes yaitu $0.105(0.105>0.05)$ dan nilai siginifikansi posttes yaitu $0.088(0.088>0.05)$. Dikarenakan nilai signifikansi dari pretes dan posttes lebih dari 0.05 yang berarti data berasal dari sampel berdistribusi normal.

\section{b. Uji Homogenitas}

Uji homogenitas menggunakan statistik uji Levene dengan taraf signifikansi 5\%. Berikut hasil dari uji homogenitas dengan menggunakan SPSS versi 25:

\section{Tabel.3.}

Hasil Uji Homogenitas

Uji homogenitas

\begin{tabular}{|c|c|}
$\mathrm{N}$ & Sig \\
\hline 32 & 0,486 \\
\hline
\end{tabular}

Berdasarkan tabel uji homogenitas di atas menghasilkan nilai signifikansi sebesar $0.486(0.486>0.05)$, hal ini menandakan bahwa data yang ada adalah homogen.

c. Uji hipotesis

Untuk menguji hipotesis ini menggunakan Uji paired t-test. Uji beda rata-rata paired $t$-test dilakukan karena data berasal dari dua kelompok dengan subjek yang sama. Uji ini menggunakan taraf signifikan 5\% dengan kriteria pengujian $\mathrm{H}_{0}$ ditolak jika $\mathrm{t}_{\text {hitung }} \geq \mathrm{t}_{\text {tabel }}$. Perhitungan seluruhnya menggunakan aplikasi SPSS versi 25. Berikut hasil perhitungan dari uji hipotesis:

Tabel.4.

Hasil Uji Hipotesis Paired t-test

\begin{tabular}{|c|c|c|c|}
\multicolumn{4}{c}{ Hasil Uji Hipotesis Paired t-test } \\
\hline \multirow{2}{*}{$\begin{array}{c}\text { paired t-test pretes dan } \\
\text { posttes }\end{array}$} & $\mathrm{N}$ & t-hitung & Sig (2-tailed) \\
\cline { 2 - 4 } & 32 & 6,713 & 0.000 \\
\hline
\end{tabular}

Berdasarkan tabel di atas didapat dilihat signifikansi (2-tailed) adalah 0.000, $\mathrm{t}_{\text {hitung }}$ sebesar 6,713 pada sampel sebanyak 32 orang peserta didik. $\mathrm{T}_{\text {tabel }}$ pada taraf signifikan 5\% dengan jumlah sampel 32 adalah 0.68249 .

Maka dapat diambil keputusan bahwa terdapat perbedaan antara hasil belajar pada data pretes dan posttes, terbukti dari adanya nilai t hitung yang lebih besar dari t tabel $(6.713>0.68249)$. Sehingga dapat dikatakan $\mathrm{H} 1$ diterima yaitu tidak sama dengan rata-rata pretes posttes atau ada peningkatan rata-rata hasil pretes dan post tes.

\section{B. Pembahasan}

Pada penelitian ini bertujuan untuk mengetahui ada atau tidaknya peningkatan dari hasil belajar peserta didik bila diterapkan model pembelajaran Problem Based Learning di kelas X SMK Angkasa Tasikmalaya. Penelitian ini dilakukan menggunakan aplikasi grup whatsapp. Aplikasi whatsapp ini digunakan karena di miliki banyak 
orang, mudah diakses, mudah difahami, mudah digunakan lewat handphone dan dapat digunakan untuk mengirim pesan gambar, suara, teks maupun dokumen.

Sampel yang digunakan adalah peserta didik kelas X semua jurusan yang memiliki handphone untuk dapat akses ke aplikasi whatsapp yaitu sebanyak 32 orang peserta didik. Penelitian dilaksanakan sebanyak 3 kali pertemuan pada bulan Agustus 2020 dari tanggal 7, 8 dan 14 Agustus 2020, materi yang diajarkan disesuaikan dengan materi pembelajaran yang sedang berlangsung yaitu logika dan algoritma.

Penelitian dilakukan untuk meningkatkan hasil belajar peserta didik, dikarenakan hasil belajar peserta didik masih belum optimal, hal ini terlihat dari nilai harian mata pelajaran simulasi digital, masih banyak yang belum mencapai nilai KKM yang telah ditentukan yaitu 75. Nilai harian peserta didik dapat dilihat pada lampiran 25. Dari 54 peserta didik nilai rata-rata sebesar 70.8. banyaknya peserta didik yang nilainya kurang dari KKM bisa disebabkan oleh beberapa faktor, salah satunya yaitu kurangnya interaksi guru dan peserta didik dikarenakan guru hanya mengirim materi dan tugas, hal ini juga akan berpengaruh terhadap kualitas lulusan yang dihasilkan, sehingga kurang bisa bersaing di dunia kerja. Setelah pemberian pretes dan posttes didapat data tiap peserta didik, yang dibuat dalam bentuk diagram sebagai berikut.

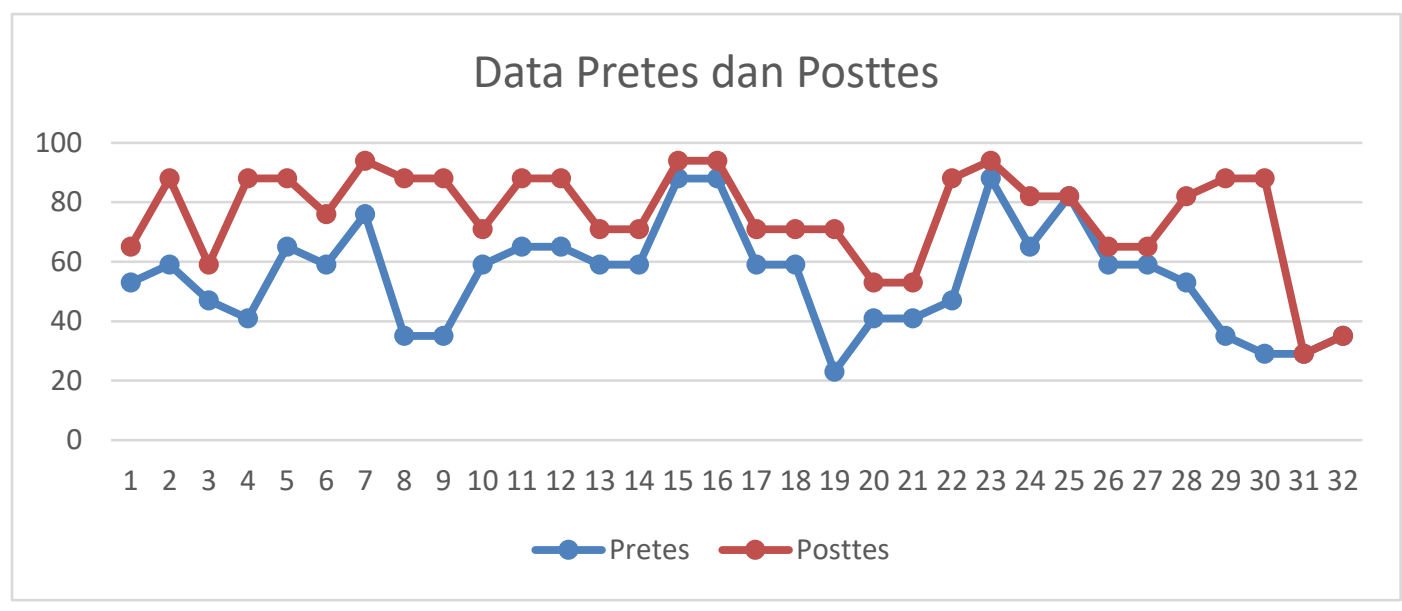

Gambar.1.

Diagram Pretes dan Posttes Persiswa

Dilihat dari diagram di atas adanya kenaikan nilai dan penurunan hasil pretes dan posttes, selanjutnya adalah menganalisis datanya, didapat hasil sebagai berikut:

Tabel.5.

Pembahasan Rekapitulasi Pretes dan Posttes

\begin{tabular}{|c|c|c|c|c|c|c|c|c|}
\hline Kelompok & N & Max & Min & Sd & $\begin{array}{c}\text { Rata- } \\
\text { Rata }\end{array}$ & selisih & Persen & Kategori \\
\hline Pretes & 32 & 88 & 23 & 17,41 & 54,90 & \multirow{2}{*}{20,96} & $50,19 \%$ & $\begin{array}{c}\text { Sukup } \\
\text { Paik }\end{array}$ \\
\hline Posttes & 32 & 94 & 29 & 16,64 & 75,87 & & \\
\hline
\end{tabular}

Berdasarkan tabel di atas didapat data bahwa ada peningkatan pada rata-rata hasil pretes dan posttes yaitu peningkatan sebesar 20.96, jika dilihat presentasinya maka kenaikan nilainya sebesar 50.19\%. Berikut disajikan dalam bentuk diagram. Peningkatan itu dilihat dari nilai rata-rata pretes sebesar 54.90 dengan kriteria cukup dan nilai rata-rata posttes sebesar 75.87 dengan kriteria sangat baik. 


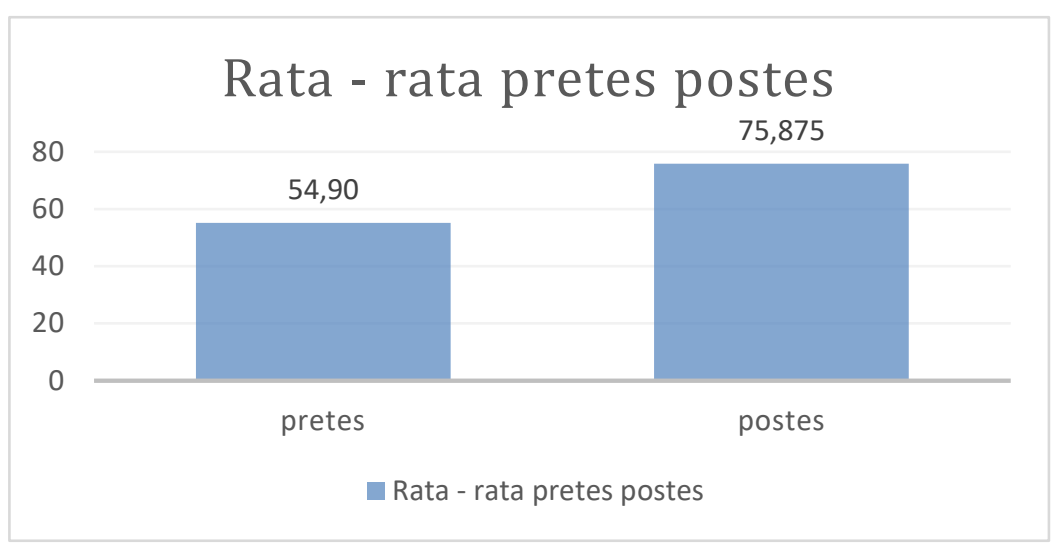

Gambar.1.

Diagram Hasil Pretes dan Posttes

\section{KESIMPULAN}

Kesimpulan pada penelitian ini adalah:

1. Penerapan model pembelajaran Problem Based Learning pada pembelajaran simulasi digital telah dilakukan melalui aplikasi grup whatsapp dengan beberapa tahap seperti tahap orientasi peserta didik, tahap organisasi peserta didik untuk belajar, tahap membimbing penyelidikan individu maupun kelompok, tahap menyajikan hasil karya dan tahap mengevaluasi proses pemecahan masalah.

2. Adanya peningkatan dalam hasil belajar peserta didik yang dilihat dari hasil rata-rata pretes dan posttes yaitu pretes 54.90 sedangkan posttes sebesar 75.87. Selisih dari kedua rata-rata adalah sebesar 20.96 yang berarti $50.19 \%$ jumlah kenaikannya.

3. Peningkatan terlihat dari nilai signifikansi $0,000<0,05$ dan thitung pada uji hipotesis yaitu sebesar 6.713 lebih dari tabel yaitu 0,68 (6.713>0.68) artinya $\mathrm{H}_{1}$ diterima yaitu bahwa penerapan model Problem Based Learning berpengaruh yang signifikan terhadap hasil belajar peserta didik.

\section{DAFTAR PUSTAKA}

[1] Doni Koesoema. 2007. Pendidikan Karakter: Mendidik Anak di Zaman Global. Jakarta: Grasindo. Abdul Majid, Dian Andayani. 2011.

[2] Hamdayama, Jumanta. 2016. Metodologi Pengajaran. Jakarta: PT. Bumi Aksara.

[3] Muhammad Abdul Haris. 2013. Pengaruh Penerapan Model Problem Based Learning Terhadap Kemampuan Memecahkan Masalah Dalam Pembelajaran Ilmu Pengetahuan Sosial Pada Siswa Kelas IV Sekolah Dasar Negeri Blondo 1 Magelang. Terdapat pada https://eprints.uny.ac.id/15968/. Diakses pada tanggal 1 Agustus 2020.

[4] Nurhadi, 2004. Pembelajaran Kontekstual dan penerapannya dalam KBK. Malang: UM Press.

[5] Rusmono. 2012. Strategi Pembelajaran dengan Problem Based Learning itu. Perlu: untuk meningkatkan Profesionalitas Guru. Bogor: Ghalia. Indonesia

[6] Sugiyono. (2016). Metode penelitian pendidikan (pendekatan kuantitatif, kualitatif dan R\&D). Bandung: Alfabeta.

[7] Sugiyono. 2018. Metode Penelitian Kuantitatif Kualitatif dan RnD. Bandung. Alfabeta.

[8] Sanjaya, Wina. (2006). Strategi pembelajaran berorientasi standar proses pendidikan. Jakarta: Kencana Prenada Media Group. 


\section{BIODATA PENULIS}

Ninu Marlina, memperoleh gelar sarjana (S,Pd), Program Studi Pendidikan Teknologi Informasi FKIP Universitas Muhammadiyah Tasikmalaya, lulus pada tahun 2020.

Alfadl Habibie, memperoleh gelar sarjana pendidikan (S,Pd) Program Studi Pendidikan Bahasa Arab, lulus tahun 2007, pada tahun 2013 memperoleh gelar Magister dari Program Studi Ilmu Pendidikan Islam UIN SGD Bandung. Saat ini menjadi Staf Pengajar Program Studi Pendidikan Teknologi Informasi di Universitas Muhammadiayah Tasikmalaya.

Sulidar Fitri, memperoleh gelar sarjana (S.Kom), Program Studi Teknik Informatika, lulus tahun 2010, pada tahun 2012 memperoleh gelar Magister dari Program Studi Teknik Informatika Asia University Taiwan. Saat ini menjadi Staf Pengajar Program Studi Pendidikan Teknologi Informasi di Universitas Muhammadiayah Tasikmalaya. 